\title{
Türkiye Ekonomisinde Büyümenin Dinamiği Olarak Enerji
}

\author{
Energy, As The Dynamic of Growth in Turkish Economy \\ Abdullah Emre ÇAĞLAR ${ }^{1}$ \\ Yeşim KUBAR ${ }^{2}$ \\ Adil KORKMAZ 3
}

Geliş tarihi: 10.04.2017, Kabul tarihi: 07.08.2017, Basım tarihi: 20.11.2017

\section{Özet}

Altyapı niteliğinde bir faktör olan enerji tüketiminin büyüme üzerindeki etkisini öngörebilmek için söz konusu iki değişken arasındaki ilişkiyi belirlemek gerekir. Bu çalışmada Türkiye'nin 1960-2014 yıllarındaki verilerine dayalı olarak anılan ilişki incelenmiştir. Analiz sonucunda büyüme ve enerji tüketimi arasında güçlü ölçülerde olumlu bir ilişki olduğu saptanmış ve Türkiye'de yüksek ölçülerde büyüme sağlayabilmek için büyüme oranına yakın yükseklikte enerji tüketiminin gerekli olduğu saptanmıştır. Dolayısıyla, politika yapıcılar Türkiye için sürekli büyüme hedefliyorsa, enerji çeşitliliği arttırılarak enerji tüketimindeki dalgalanmalar en aza indirilmelidir.

Anahtar Kelimeler: Ekonomik. Büyüme, Enerji Tüketimi, Yapısal Kırlmalı Eşbütünleşme.

Jel Kodlar1: C32, O40, Q40.

\begin{abstract}
In order to foresee the effect of energy consumption, which can be considered as part of infrastructure, on growth, it is necessary to determine the relation between these two variables. In this study, the aim is to examine the abovementioned relation based on the data between the years 1960-2014 in Turkey. Findings of the analysis suggest that there is strong and positive relationship between growth and energy consumption; and it is also found out that in order to ensure highlevel growth in Turkey, energy consumption must be close to the growth rate. For this reason, if policy-makers aim a continuous development for Turkey, energy variety must be increased, and the fluctuations in the energy consumption must be reduced.
\end{abstract}

Keywords: Economic Growth, Energy Consumption, Cointegration Test with Structural Breaks.

Jel Codes: C32, O40, Q40.

\footnotetext{
1 Akdeniz Üniversitesi İktisadi ve İdari Bilimler Fakültesi, Ekonometri Bölümü, Arş. Gör. aecaglar@akdeniz.edu.tr

${ }^{2}$ Fırat Üniversitesi İktisadi ve İdari Bilimler Fakültesi, İktisat Bölümü, Yrd. Doç. Dr. ykubar@firat.edu.tr

3 Akdeniz Üniversitesi İktisadi ve İdari Bilimler Fakültesi, Ekonometri Bölümü, Doç. Dr. adilkorkmaz@akdeniz.edu.tr
} 


\section{Giriş}

Globalleşme sürecinde ülke ekonomileri büyürken enerjiye gittikçe daha çok gereksinim duymaktadırlar. Ülkeler, artan bu enerji gereksinimlerinin bir sonucu olarak yenilenebilen ya da yenilenemeyen enerji kaynaklarını çeşitlendirmeye ve böylece enerji güvenliğini sağlamaya yönelmektedirler. 1971-73 döneminde baş gösteren I. petrol krizinden sonra bu eğilimin eskisine göre çok daha güçlü ölçülere ulaştı̆ğ görülmektedir. Söz konusu krizde enerji fiyatlarında meydana gelen artışlar bütün ülkelerin ekonomilerini sarsmış; ancak gelişmekte olan ülke ekonomilerini daha çok etkilediği gözlemlenmiştir. Sanayi sektöründe petrol bakımından dışa bağımlı olan ülkeler bu sarsıntıyı ekonomik kriz olarak yaşamışlardır. Büyüme için kullanabilecekleri döviz kaynaklarının büyük bir bölümünü petrol ithalatını karşılamak için kullanmışlar ve böylece yatırım malları ithalatında kısıntıya gitmek zorunda kalmışlardır. Ancak Latincedeki "Quae nocent docent: Yaralayan, öğretir de" sözünü bir kez daha doğrulamak üzere ülkeler yaşadıklarından ders alarak enerji ihtiyaçlarını karşılayabilmek için çeşitli projeler geliştirmeyi de zamanla öğrenmişlerdir.

Başka ülkeler gibi Türkiye'nin de ekonomisinde büyük sarsıntılar yaratan bu krizden dersler çıkardı̆̆1 görülmektedir. Türkiye, enerji kaynaklarını çeşitlendirip enerji güvenliğini yükseltmek için çok kapsamlı bir enerji politikası geliştirmiş ve hala geliştirmektedir. Bu politikanın amacı, iktisadî büyüme ve sosyal refahı yükseltme amacını güvence altına almaktır. Enerji politikası bağımsız bir politika değil, iktisat politikasının başarısına zemin hazırlayan bağımlı bir politikadır. Türkiye'nin enerji politikası, üretim ve tüketim dengesini gözetip yeterli, güvenilir ve ulusal kaynaklardan elde edilen bir enerji yapısı sağlama amacını gerçekleștirmeye çalıșmaktır. Ayrıca, doğubatı koridorunda bir enerji köprüsü oluşturarak enerjide dışa bağımlılı̆̆1 azaltmaya çabalarken bütün amaç elbette büyümeyi sağlamak ve sosyal refahı artırmaktır (İKV, 2004: 35).

Türkiye'nin enerji politikasını değerlendirebilmek için kendisinin destek olmaya çabaladığı büyüme ve sosyal refahı artırma politikasını anlamak gerekmektedir. Sanayileşme atılımları yaparak gelişmiş ülkeleri yakalamayı hedefleyen Türkiye, hedeflediği yolda ilerlerken rekabet kurallarının işlediği, özel sektörün ekonomide öncü olduğu, kamunun ise düzenleyici rol oynadığı, liberal dış ticaret politikasının uygulandığı, mal ve hizmetlerin bireyler ve kurumlar arasında engelsiz olarak el değiştirebildiği bir serbest piyasa ekonomisini kendisine bir kısıt olarak almaktadır. Bu konuda öylesine kararlıdır ki, son yıllarda ekonomide bu doğrultudaki yapisal reformlara ivme bile kazandırdığı görülmektedir. 2000’li y1llarda özelleştirme süreci hızlandırılmış, kamu maliyesine düzen getirilmiş, ayrıca mali piyasalardan başlamak üzere tarım, sosyal güvenlik, enerji ve iletişim gibi sektörlerde önemli reformlar gerçekleştirilmiştir. Reformlar sayesinde ekonomik 
kurumlarının altyapısı güçlendirilmiş, böylece, uluslararası piyasalarda meydana gelebilecek dalgalanmalara karşı Türkiye ekonomisi, daha dayanıklı bir duruma getirilmiştir. (MFA,2017). Etkin kullanılan politikaların bir sonucu olarak dünyanın 18. ve Avrupa'nın 7. büyük ekonomisi olan Türkiye, en güçlü ekonomilerin temsil edildiği G-20'nin faal bir üyesi konumundadır.

Türkiye, İktisadi İşbirliği ve Kalkınma Teşkilatı (OECD) ülkeleri içerisinde geçtiğimiz 10 yıllık dönemde enerji talep artışının en hızlı gerçekleştiği ülke olmuştur. Aynı şekilde dünyada 2002 yllından bu yana elektrik ve doğal gazda Çin'den sonra en fazla talep artış hızına sahip ikinci büyük ekonomidir. Yapılan projeksiyonlar bu eğilimin orta ve uzun vadede de devam edeceğini göstermektedir. Türkiye hazırladığı Orta Vadeli Planda (OVP), istikrarlı ve kapsayıc1 niteliğiyle büyümeyi artırmak, enflasyonu düşürmek, cari açıtaki azalma eğilimini korumak, ekonominin rekabet gücünü, istihdam ve verimlilik düzeyini artırmak, mali disiplinin kalitesini artırmak ve kamu maliyesini güçlendirmek ilkelerini sergilerken büyüme ve sosyal refahı artırma amacının da olduğunu uyguladığı politikalarla göstermektedir. Bunlarında:

Beşeri sermayenin geliştirilmesi, işgücü piyasasının etkinleştirilmesi, teknoloji ve yenilik geliştirme kapasitesinin artırlması, fiziki altyapının güçlendirilmesi, kurumsal kalitenin iyileştirilmesi gibi beş temel eksen üzerinde olduğu düşünülmektedir. Türkiye, yukarıda değinilen büyüme ve sosyal refahı artırma hedeflerine ulaşmak için enerjiyi kesintisiz, güvenilir, temiz ve ucuz yollardan bulmak ve bu kaynakları da mutlaka çeşitlendirerek enerji güvenliğini sağlamak durumundadır. Çünkü sürdürülebilir gelişme ve büyüme politikaları enerji sektöründe baş gösterecek darboğazlarla ilerleyememektedir (Kar ve Kınık, 2008:334).

Türkiye'de özellikle 1980 sonrasında nüfus artışı ve sanayileşmenin hız kazanması ile birlikte enerji tüketiminin hızla arttı̆̆1 gözlemlenmektedir. Neolibaral politikalar Türkiye'nin dışa açılımını artırırken sanayi ve hizmet sektörlerinin payları ile birlikte enerji tüketiminin de yükselmesine yol açmaktadır (Yanar ve Kerimoğlu, 2011:193). Böylece, elektrik arzında yetersizlik ya da doğalgaz ve petrol tedarikinde yaşanan daralmalar büyümede ve sosyal refahı arttırmada başarı eksikliği olarak geri dönmektedir. Nitekim enerjinin azalan arzı, girdi fiyatlarını arttırmakta, bu artış genel enflasyon oranında bir artışa yol açmakta, malların fiyatlarını yükseltmekte ve büyüme oranına denk gelecek bir biçimde toplam talebi azaltmaktadır (Mallick, 2007:5).

Hızla artan enerji talebi neticesinde Türkiye'nin, başta petrol ve doğal gaz olmak üzere, enerji ithalatına bağımlılı̆̆ artmaktadır. Ülkemizin hali hazırda toplam enerji talebinin yaklaşık \%25'şi yerli kaynaklardan karşılanırken, kalan bölümü çeşitlilik arz eden ithal kaynaklardan karşılanmaktadır. Türkiye, çok yönlü enerji stratejisi için, kaynak ülke ve güzergâh çeşitliliğine gidilmesini, enerji karışımında yenilenebilir enerjinin payını arttırırken, nükleer enerjiden 
de yararlanılmaya başlanılmasını, enerji verimliliğinin arttırılmasına yönelik çalışmalarda bulunulmasını amaçlamaktadır (MFA,2017).

Yukarıda değinilen enerji bağımlılığ bir ölçüde enerji güvenliğiyle yakından ilgili bir sorundur. Türkiye bu sorunu aşmış değildir ve enerji de \%70-80'lik bir oranda ithalata bağımlı olmasıyla enerji sektörünün güvenli bir durumda olmaktan uzak olduğunu kanıtlamaktadır. Dünyada yaşanan sıcak ve soğuk savaşların temelinde, enerji kaynaklarına sahip olma, taşıma yollarını ve son yllarda da giderek artan oranda, enerjinin ticaretini kontrol altında tutma çabalarının göz önünde tutulursa daha güvenli enerji politikaları belirlemenin ivediliği kendiliğinden ortaya çıkmaktadır. (Özata, 2010: 2).

Yukarıda tartışlan Türkiye'nin enerji politikaları hakkında literatürde birçok çalışma yer almaktadır. Bu çalışmanın motivasyonunu yukarıda da sıkça vurgulanan Türkiye'nin enerji güvenliğinin sağlanması ve büyüme üzerinde enerji tüketimi etkisinin nasıl olacağı sorusu oluşturmaktadır. Ayrıca savaşlar, doğal afetler, siyasi krizler vb. gibi olaylar ülkelerin ekonomik politikalarını şekillendirmede önemli rol oynamaktadır. Çalışmada bu tür olağandışı olayların etkisinden değisskenler arındırılarak güncel veri seti kullanılacaktır. Bu kapsamda tek kırilmayı dikkate alan Zivot ve Andrews (1992) birim kök testi ve yine tek kırılmayı dikkate alan Gregory ve Hansen (1996) eşbütünleşme yöntemi kullanılacaktır. Çalışma dört bölümden oluşmaktadır: Türkiye'nin enerji politikalarının geçmişten bugüne geçirdiği serüvenin tartışıldığı giriş bölümünden sonra, ikinci bölümde büyüme ve enerji tüketimi arasındaki ilişkiyi inceleyen çalışmalar gösterilecektir. Analizde kullanılan yöntemlerin anlatıldığı üçüncü bölümden sonra analizde kullanılan veriler tanıtılacak ve ampirik uygulama sonucunda elde edilen bulgular özetlenecektir. Son bölümde ise ulaşılan sonuçlar literatür çerçevesinde tartışlarak politika önerisi getirilecektir.

\section{Türkiye'de Enerjinin Görünümü}

Türkiye enerji konusunda çeşitlendirmeye gitme politikası uygulamaktadır. Bunun nedenlerinden birini ekonomik büyümenin, beraberinde getirdiği enerji tüketiminde görülen artış oluşturmaktadır. Yerli kaynaklardan üretilen enerji, artan talebi karşılamada yetersiz kalmaktadır. Yerli kaynakların yetersizliği Türkiye'yi \%70-80 oranında ithal enerji kaynaklarına bağımlı hale getirmektedir. Artan ithal enerji faturası, zaman içinde cari açığın da artmasının en önemli nedenlerinden birini oluşturmaktadır. Bu durum, enerji ithalatının azaltılması yolunda yeni politikalar geliştirilmesini kaçınılmaz kılmaktadır. Eneriji alanındaki politika ve stratejileri daha ileriye taşımak üzere 2023 hedefleri kapsamında enerji alanında başlatılan vizyon çalışmaları, Enerji ve Tabii Kaynaklar Bakanlığının (ETKB) 2015-2019 Stratejik Planı ile devam etmektedir. Temel hedef olarak enerjide dışa bağımlılığı azaltma ekseninde düzenlenen bu politikalar, Türkiye'nin geleceğine yön verici özelliktedir. Türkiye için önemli bir konu olan enerji, geliştirilen politika ve stratejiler 
çerçevesinde şekillenmeyi sürdürmektedir. Son y1llarda ulusal ve uluslararası arenada enerji konusunda kritik bir misyon üstlenen Türkiye, bu doğrultudaki politikalarını güçlendirerek devam ettirmektedir. Milli Enerji ve Maden Politikası da bu amaçla gündeme gelmiş ve ortaya attığ stratejilerle Türkiye'nin küresel enerji piyasalarındaki konumunu sağlamlaştırmak adına programlanmıştır (Karagöl vd,2017;8-9).

Enerji üzerini yapılan senaryolara göre, 2040 yllına kadar olan dönemde fosil yakıtların paylarının azalmasına rağmen bu yakıtların yine de hakim kaynaklar olmaya devam edeceği öngörülmektedir. Nükleer enerjinin birincil enerji kaynakları içindeki payının artacağı, yenilenebilir enerji kaynaklarının 2040 yllındaki payının \%16,1 olacağ1 beklenmektedir. Yenilenebilir enerji kaynakları yıllık ortalama $\% 9,8$ büyüme payları ile en hızlı büyüme oranına sahip enerji kaynaklarıdır. Nükleer enerji yıllık ortalama $\% 2,3$ ve hidroelektrik ylllı ortalama $\% 1,8$ büyüme oranına sahip olacağı beklenmektedir. Bu üç kaynağın büyüme oranı, toplam birincil enerjinin büyüme oranından daha fazla olmaktadır. Fosil yakıtlar arasında en fazla büyüme oranına sahip olan kaynak yıllık ortalama \%1,5 büyüme oranı ile doğal gazdır. Doğal gazı sırasıyla ylllı ortalama $\% 0,4$ ve $\% 0,2$ büyüme oranlarr ile petrol ve kömür izlemektedir (http://enerij.gov.tr).

2014 yllında 125,3 mtpe olan Türkiye'nin birincil enerji talebinin 2023 yll itibarıly 218 mtpe'ye ulaşması beklenmektedir. Birincil enerji talebinin \%35'i doğal gazdan, \%28,5'u kömürden, \%27'si petrolden, \%7'si hidroelektirk santrallerinden, \%2,5'u da diğer yenilenebilir enerji kaynaklarından sağlanmaktadır. Önemli bir nokta tüketilen doğal gazın yaklaşık \%99'u ve petrolün \%89'nun ithal edilmesidir. Bu nedenle, Türkiye'nin yenilenebilir enerji kaynaklarının enerji talebi içindeki payını yükselterek ve nükleer enerjiden faydalanarak; enerjide kaynak bağımlılığını azaltama, yerli kaynak kullanımını maksimize etme ve iklim değişikliğiyle mücadele etme yönünde politikalarını sürdürmesinin gerekli olduğu düşünülmektedir.

Türkiye dünyada, birincil enerji tüketiminde 19. sırada yer almaktadır. Türkiye'nin ve bazı ülkelerin birincil enerji tüketimleri tablo 1 de verilmiştir.

Tablo 1: Bazı Ülkelerin Birincil Enerji Tüketimi

\begin{tabular}{|l|l|l|l|l|l|}
\hline ÜLKE & $\mathbf{2 0 1 3}$ & $\mathbf{2 0 1 4}$ & $\mathbf{2 0 1 5}$ & $\begin{array}{l}\text { Dünya Toplamındaki } \\
\text { Pay1 (\%) }\end{array}$ & Sira \\
\hline Cin & $2.903,9$ & $2.970,3$ & $3.014,0$ & $22,9 \%$ & 1 \\
\hline ABD & $2.271,7$ & $2.300,5$ & $2.280,6$ & $17,3 \%$ & 2 \\
\hline Hindistan & 626,0 & 666,2 & 700,5 & $5,3 \%$ & 3 \\
\hline Rusya & 688,0 & 689,8 & 666,8 & $5,1 \%$ & 4 \\
\hline
\end{tabular}


Türkiye Ekonomisinde Büyümenin Dinamiği Olarak Enerji

\begin{tabular}{|c|c|c|c|c|c|}
\hline Japonya & 465,8 & 453,9 & 448,5 & $3,4 \%$ & 5 \\
\hline Kanada & 335,0 & 335,5 & 329,9 & $2,5 \%$ & 6 \\
\hline Almanya & 325,8 & 311,9 & 320,6 & $2,4 \%$ & 7 \\
\hline Brezilya & 290,0 & 297,6 & 292,8 & $2,2 \%$ & 8 \\
\hline Güney Kore & 270,9 & 273,1 & 276,9 & $2,1 \%$ & 9 \\
\hline Iran & 247,6 & 260,8 & 267,2 & $2,0 \%$ & 10 \\
\hline Sundi Arabistan & 237,4 & 252,4 & 264,0 & $2,0 \%$ & 11 \\
\hline Fransa & 247,4 & 237,5 & 239,0 & $1,8 \%$ & 12 \\
\hline Endonesya & 175,0 & 188,3 & 195,6 & $1,5 \%$ & 13 \\
\hline Birleşik Kralluk & 201,4 & 188,9 & 191,2 & $1,5 \%$ & 14 \\
\hline Meksika & 188,9 & 190,0 & 185,0 & $1,4 \%$ & 15 \\
\hline İtalya & 155,7 & 146,8 & 151,7 & $1,2 \%$ & 16 \\
\hline Ispanya & 134,2 & 132,1 & 134,4 & $1,0 \%$ & 17 \\
\hline Avustralya & 130,7 & 129,9 & 131,4 & $1,0 \%$ & 18 \\
\hline Türkiye & 120,3 & 123,9 & 126,9 & $1,0 \%$ & 19 \\
\hline Tayland & 120,3 & 123,4 & 124,9 & $0,9 \%$ & 20 \\
\hline Güney Afrika & 124,6 & 128,0 & 124,2 & $0,9 \%$ & 21 \\
\hline Tayvan & 109,9 & 111,4 & 110,7 & $0,8 \%$ & 22 \\
\hline$B A E$ & 97,2 & 99,0 & 103,9 & $0,8 \%$ & 23 \\
\hline Polonya & 96,0 & 92,4 & 95,0 & $0,7 \%$ & 24 \\
\hline Ukrayna & 114,7 & 101,0 & 85,1 & $0,6 \%$ & 25 \\
\hline TOPLAM & $12.873,1$ & $13.020,6$ & $13.147,3$ & $100,0 \%$ & \\
\hline
\end{tabular}

Kaynak:http://enerij.gov.tr/File/?path=ROOT $\% 2 \mathrm{f1} \% 2 \mathrm{fD}$ ocuments $\% 2 \mathrm{fEnerji} \% 2$ Ove $\% 20$ Tabii $\%$; s.6

Dünya ve Türkiye de birincil enerji tüketiminin artmasının temel nedenleri arasında nüfus ve gelir artışı gelmektedir. Nüfus artışının gelişmekte olan sanayi ve kentleşmelere bağlı olarak küresel enerji talep artsşına önemli 108 
miktarda etki edeceği öngörülmektedir. OECD dışı ülkelerin yaratacağı bu etki Şekil 1.'de verilen nüfus, GSYH büyüme oranı ve birincil enerji talebi projeksiyonlarında görülmektedir.

\section{Şekil 1: Nüfus, GSYİH Büyüme Oranı ve Birincil Enerji Talebi Projeksiyonlar1}

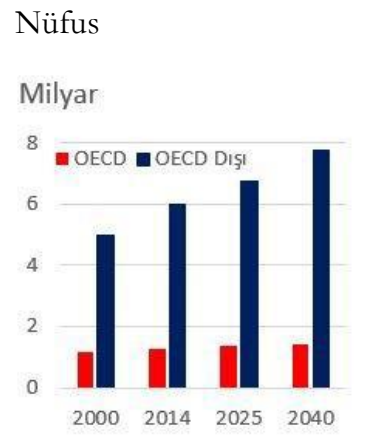

GSYH Büyüme Oranı Birincil Enerji talebi

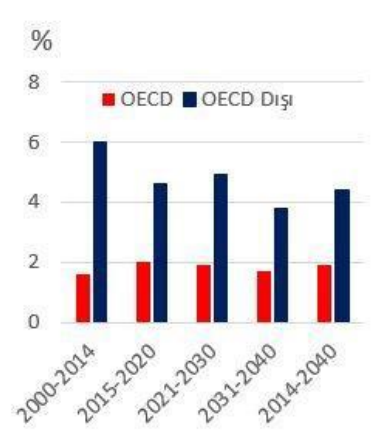

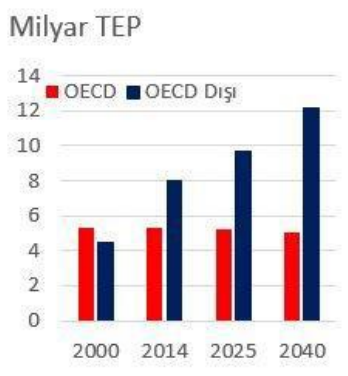

Şekil-1 de, OECD dışı ülkelerin 2000-2040 dönemi senaryosuna göre OECD ülkelerinden daha yüksek bir nüfus artısına sahip olacağı, ekonomik büyümenin de OECD dışı ülkelerde daha yüksek gerçekleşeceği, bu iki etkinin bir sonucu olarak OECD dışı ülkelerde 2014-2040 döneminde birincil enerji talebinin OECD ülkelerinden daha yüksek olacağı görülmektedir.

Yapılan senaryolara göre, 2040 yilına kadar olan dönemde fosil yakıtların paylarının azalmasına karşın bu yakıtlar yine de hakim kaynaklar olmaya devam edeceği Nükleer enerjinin birincil enerji kaynakları içindeki payının artacağ1 öngörülmektedir. Yenilenebilir enerji kaynakları en hızlı büyüme oranına sahip enerji kaynaklanıdır, Nükleer enerjinin yıllık ortalama $\% 2,3$ ve hidroelektrik enerjinin yıllık ortalama $\% 1,8$ büyüme oranına sahip olacağ1 öngörülmektedir (http://enerji.gov.tr).

\section{Büyüme ve Enerji Tüketimi İlişkisi Özet Literatür Taraması}

Dünyada enerji tüketimi ve ekonomik büyüme arasında yapılmış birçok ampirik çalışma bulunmaktadır. Ampirik literatür incelendiğinde enerji tüketimi ve ekonomik büyüme hakkında farklı ve birbiriyle çelişen bulgulara rastlanmaktadır. Bu farklılıklar; ülkelerin sahip olduğu iklim koşullarının farklı olmas1, ekonomik kalkınma düzeylerinin yan1 sıra enerji tüketim alışkanlıklarının birbirlerine benzememesi, farklı ekonometrik yöntemlerin kullanılması ve veri setlerinin değişmesinden kaynaklanmaktadır (Belke vd., 2010:6).

Türkiye'de ilgili değişkenler kullanılarak yapılan çalışmaların sonuçları, diğer ülkelerle yapılan çalısmaların sonuçlarına göre farklılıklar göstermektedir. Bu farklılıkların nedenleri arasında; farklı yılları kapsayan 
zaman aralıkları, farklı ekonometrik yöntemler, farklı veri kümelerinin kullanılması yer almaktadır. Türkiye ekonomisi için, enerji tüketimi ve büyüme arasındaki ilişkiyi inceleyen birçok çalışma yapılmış ve farklı nedensellik sonuçlarına ulaşılmışıı. Bu çalışmalardan bazıları aşağıdaki tablo 2 yardımıyla Özetlenebilir.

\section{Tablo 2: Literatür Özeti}

\begin{tabular}{|c|c|c|c|c|}
\hline Çalışma & Dönem & Ülke & $\begin{array}{l}\text { Ekonometrik } \\
\text { Yöntem }\end{array}$ & Bulgular \\
\hline $\begin{array}{l}\text { Kraft ve } \\
\text { Kraft (1978) }\end{array}$ & $1947-1974$ & $\mathrm{ABD}$ & $\begin{array}{l}\text { Sims } \\
\text { Metodolojisi }\end{array}$ & $\begin{array}{l}\text { Öncü olarak kabul edilen bu çalışmanı̈n } \\
\text { sonucunda büyümeden enerji tüketimine } \\
\text { doğru tek yönlü bir ilişki olduğu } \\
\text { bulgusuna ulaşılmıştır. }\end{array}$ \\
\hline $\begin{array}{l}\text { Hamilton } \\
(1983)\end{array}$ & $1948-1972$ & $\mathrm{ABD}$ & $\begin{array}{l}\text { Granger } \\
\text { Nedensellik } \\
\text { Testi }\end{array}$ & $\begin{array}{l}\text { Çalışmada, enerji fiyatının büyümenin } \\
\text { nedeni olduğu sonucuna ulaşılmıştır. }\end{array}$ \\
\hline $\begin{array}{l}\text { Burbridge ve } \\
\text { Harrison } \\
\text { (1984) }\end{array}$ & 1961-1982 & $\begin{array}{l}\text { ABD, } \\
\text { Japonya, } \\
\text { Ingiltere, } \\
\text { Almanya, } \\
\text { Kanada }\end{array}$ & Sims Tekniği & $\begin{array}{l}\text { Çalışmada enerji fiyatının büyümenin } \\
\text { nedeni olduğu sonucuna ulaşılmıştır. }\end{array}$ \\
\hline $\begin{array}{l}\text { Yu ve } \\
\text { Huwang } \\
\text { (1984) }\end{array}$ & $1947-1979$ & $\mathrm{ABD}$ & Sims Tekniği & $\begin{array}{l}\text { Çalışmada, enerji tüketimi ve büyüme } \\
\text { ilişkisi arasındaki ilişki ve istihdam ile } \\
\text { enerji tüketimi arasındaki nedensellik } \\
\text { ilişkisi incelenmiş ve istihdamdan enerji } \\
\text { tüketimine doğru tek yönlü zayıf bir } \\
\text { ilişki olduğu sonucuna ulaşılmıştır. }\end{array}$ \\
\hline $\begin{array}{l}\text { Hwang ve } \\
\text { Gum (1992) }\end{array}$ & $1961-1990$ & Tayvan & $\begin{array}{l}\text { Granger } \\
\text { Nedensellik } \\
\text { testi }\end{array}$ & $\begin{array}{l}\text { Çalışmada, Tayvan'da iki yönlü } \\
\text { nedensellik bulunduğu bulgusuna } \\
\text { ulaşılmıştır. }\end{array}$ \\
\hline $\begin{array}{l}\text { Yu ve Jin } \\
(1992)\end{array}$ & & Amerika & $\begin{array}{l}\text { Eşbütünleşme } \\
\text { Modeli }\end{array}$ & $\begin{array}{l}\text { Çalışmada, enerji kullanımı ve büyüme } \\
\text { arasında herhangi bir ilişki bulunmadığ1 } \\
\text { sonucuna ulaşılmıştır. }\end{array}$ \\
\hline Stern (1993) & $1947-1990$ & $\mathrm{ABD}$ & $\begin{array}{l}\text { Granger } \\
\text { Nedensellik } \\
\text { testi }\end{array}$ & $\begin{array}{l}\text { Çalışmada, enerjinin büyümenin nedeni } \\
\text { olduğu sonucuna ulaşılmıştır. }\end{array}$ \\
\hline $\begin{array}{l}\text { Masih ve } \\
\text { Masih (1996) }\end{array}$ & $1955-1990$ & $\begin{array}{l}\text { Hindistan, } \\
\text { Pakistan, } \\
\text { Endonezya, } \\
\text { Malezya, } \\
\text { Singapur, } \\
\text { Filipinler }\end{array}$ & $\begin{array}{l}\text { Eşbütünleşme } \\
\text { ve Granger } \\
\text { nedensellik } \\
\text { yöntemleri }\end{array}$ & $\begin{array}{l}\text { Çalışmada, enerji ile büyüme arasında } \\
\text { Hindistan, Pakistan ve Endonezya'da } \\
\text { eşbütünleşme olduğu, Malezya, Singapur } \\
\text { ve Filipinler'de eşbütünleşmeun } \\
\text { olmadığı; Hindistan'da nedenselliğin } \\
\text { enerjiden büyümeye doğru, Pakistan ve } \\
\text { Endonezya'da ise büyümeden enerijye } \\
\text { doğru olduğu sonucuna ulaşılmıştır. }\end{array}$ \\
\hline
\end{tabular}




\begin{tabular}{|c|c|c|c|c|}
\hline $\begin{array}{l}\text { Cheng ve Lai } \\
\text { (1997) }\end{array}$ & $1955-1993$ & Tayvan & $\begin{array}{l}\text { Granger } \\
\text { Nedenselliği ve } \\
\text { Hsiao } \\
\text { versiyonu }\end{array}$ & $\begin{array}{l}\text { Çalışmada, nedenselliğin ekonomik } \\
\text { büyümeden enerij tüketimine doğru } \\
\text { olduğu sonucuna ulaşıllmıştır. }\end{array}$ \\
\hline Stern $(2000)$ & 1948-1994 & $\mathrm{ABD}$ & $\begin{array}{l}\text { Eşbütünleşme } \\
\text { analizi }\end{array}$ & $\begin{array}{l}\text { Çalışmada, enerji kullanımı ve büyüme } \\
\text { arasında eşbütünleşme iliş̧kisi olduğu } \\
\text { sonucuna ulaşılmıştır. }\end{array}$ \\
\hline Yang (2000) & $1957-1997$ & Tayvan & $\begin{array}{l}\text { Granger } \\
\text { nedensellik } \\
\text { testi }\end{array}$ & $\begin{array}{l}\text { Çalışsmada, enerji tüketimi ile ekonomik } \\
\text { büyüme arasında çift yönlü nedensellik } \\
\text { ilişkisi olduğu sonucuna ulaşılmıştır. }\end{array}$ \\
\hline $\begin{array}{l}\text { Aqeel ve } \\
\text { Butt (2001) }\end{array}$ & $1955-1996$ & Pakistan & $\begin{array}{l}\text { Granger } \\
\text { Nedenselliği ve } \\
\text { Hsiao } \\
\text { versiyonu }\end{array}$ & $\begin{array}{l}\text { Çalışma sonucunda, ekonomik } \\
\text { büyümenin enerji tüketimine neden } \\
\text { olduğu belirlenmiştir. }\end{array}$ \\
\hline $\begin{array}{l}\text { Glasure } \\
(2002)\end{array}$ & $1961-1990$ & Kore & $\begin{array}{l}\text { Granger } \\
\text { Nedensellik } \\
\text { Yöntemi }\end{array}$ & $\begin{array}{l}\text { Çalışmada, enerji ve gelir arasında } \\
\text { eşbütünleşme ve iki yönlü nedenselliğin } \\
\text { zayıf olduğunu tespit etmişlerdir. }\end{array}$ \\
\hline $\begin{array}{l}\text { Paul ve } \\
\text { Bhattacharya } \\
\text { (2004) }\end{array}$ & $1950-1996$ & Hindistan & $\begin{array}{l}\text { Eşbütünleşme } \\
\text { analizi ve } \\
\text { Granger } \\
\text { nedensellik } \\
\text { testi }\end{array}$ & $\begin{array}{l}\text { Çalışmada, Enerji tüketimi ve ekonomik } \\
\text { büyüme arasında çift yönlü ilişsi olduğu } \\
\text { sonucuna ulaşılmıştır. }\end{array}$ \\
\hline $\begin{array}{l}\text { Lee ve } \\
\text { Chang } \\
(2005)\end{array}$ & $1954-2003$ & Tayvan & $\begin{array}{l}\text { Birim kök testi, } \\
\text { Eşbütünleşme } \\
\text { analizi, Zayıf } \\
\text { dısssallık testi }\end{array}$ & $\begin{array}{l}\text { Çalış̧mada, uzun dönemde eneriinin } \\
\text { ekonomik büyümenin lokomotifi } \\
\text { olduğu, dolayisıyla enerjii tasarrufunun } \\
\text { ekonomik büyümeye zararlı olacağı } \\
\text { belirtilmiş, Ayrıca enerji tüketimi ve gayri } \\
\text { safi yurt içi hasıla arasındaki } \\
\text { eşbütünleşmeun istikrarsız olduğu, bazı } \\
\text { ekonomik olayları etkilediği sonucunu } \\
\text { uluşılmış̧ır. }\end{array}$ \\
\hline $\begin{array}{l}\text { Zou ve Chau } \\
\text { (2006) }\end{array}$ & $\begin{array}{l}\text { 1953-2002 } \\
1953-1985 \\
\text { ve } \\
\text { 1985-2002 } \\
\text { iki alt } \\
\text { döneme } \\
\text { ayırarak }\end{array}$ & Çin & $\begin{array}{l}\text { Eşbütünleşme } \\
\text { analizi ve } \\
\text { Granger } \\
\text { nedensellik } \\
\text { testi }\end{array}$ & $\begin{array}{l}\text { Çalış̧mada, Eşbütünleşme testleri uzun } \\
\text { dönemde petrol tüketimi ile ekonomik } \\
\text { büyümenin aynı yönde hareket ettiği, } \\
\text { Granger de ise 1953-2002 döneminde } \\
\text { petrol tüketimi ile ekonomik büyüme } \\
\text { arasında çift yönlü nedensellik ilişsisi } \\
\text { olduğu, Analiz dönemi boyunca ister } \\
\text { uzun dönemde, isterse kısa dönemde söz } \\
\text { konusu iki değişsenin birbirlerinin } \\
\text { nedeni olduğunu sonucuna ulaşılmışıtır. }\end{array}$ \\
\hline
\end{tabular}




\begin{tabular}{|c|c|c|c|c|}
\hline $\begin{array}{l}\text { Mahadevan } \\
\text { ve Asafu- } \\
\text { Adjaye } \\
(2007)\end{array}$ & $1971-2002$ & $\begin{array}{l}\text { Avustralya, } \\
\text { Norveç, } \\
\text { İngiltere, } \\
\text { Japonya, } \\
\text { İsveç, ABD, } \\
\text { Arjantin, } \\
\text { Endonezya, } \\
\text { Kuveyt, } \\
\text { Malezya, } \\
\text { Nijerya, } \\
\text { Suudi } \\
\text { Arabistan, } \\
\text { Venezüela, } \\
\text { Gana, } \\
\text { Hindistan, } \\
\text { Senal, Güney } \\
\text { Afrika, } \\
\text { Güney Kore, } \\
\text { Singapur, } \\
\text { Tayland }\end{array}$ & $\begin{array}{l}\text { Birim kök testi, } \\
\text { Eşbütünleşme } \\
\text { analizi, Granger } \\
\text { nedensellik } \\
\text { analizi }\end{array}$ & $\begin{array}{l}\text { Çalışmada, enerji ihracatçısı olan ülkeler } \\
\text { için, kısa dönemde enerji tüketimi ile } \\
\text { ekonomik büyüme arasında çift yönlü } \\
\text { bir büyüme ilişkisinin oldugu, Uzun } \\
\text { dönemde ise, büyümeden enerji } \\
\text { tüketimine doğru tek yönlü bir ilişkinin } \\
\text { olduğu, Enerji ithalatçısı ülkeler için } \\
\text { enerji tüketimi ve büyüme karşılılı } \\
\text { olarak birbirinin nedenidir sonucunu } \\
\text { ulaşılmıştır. }\end{array}$ \\
\hline $\begin{array}{l}\text { Yuan, Zhao, } \\
\text { Yu ve } \mathrm{Hu} \\
(2007)\end{array}$ & $1978-2004$ & Çin & $\begin{array}{l}\text { Eşbütünleşme } \\
\text { ve Ko-feature } \\
\text { Analizleri }\end{array}$ & $\begin{array}{l}\text { Çalışmada, Çin için elektrik tüketimi ile } \\
\text { GSYH arasında eşbütünleşme olduğu, } \\
\text { yalnızca enerji tüketiminden ekonomik } \\
\text { büyümeye doğru tek yönlü bir Granger } \\
\text { nedenselliğinin olduğu sonucuna } \\
\text { ulaşılmıştır. }\end{array}$ \\
\hline Payne (2009) & $1949-2006$ & $\mathrm{ABD}$ & $\begin{array}{l}\text { Toda- } \\
\text { Yamamato } \\
\text { Nedensellik } \\
\text { Analizi }\end{array}$ & $\begin{array}{l}\text { Çalışmada, enerji tüketimi ve ekonomik } \\
\text { büyüme arasında herhangi bir } \\
\text { nedensellik ilişkisinin olmadığı sonucuna } \\
\text { ulaşılmıştır. }\end{array}$ \\
\hline $\begin{array}{l}\text { Odhiambo } \\
(2009)\end{array}$ & $1971-2006$ & $\begin{array}{l}\text { Güney } \\
\text { Afrika }\end{array}$ & $\begin{array}{l}\text { Durağanlık } \\
\text { Testi, } \\
\text { Eşbütünleşme } \\
\text { Analizi, } \\
\text { Granger } \\
\text { Nedensellik } \\
\text { Testi }\end{array}$ & $\begin{array}{l}\text { Çalışmada, Güney Afrika'da enerji } \\
\text { tüketimi ve ekonomik büyüme arasında } \\
\text { belirgin bir çift yönlü nedensellik olduğu } \\
\text { ayrıca istihdamın da ekonomik } \\
\text { büyümenin Granger nedeni olduğu } \\
\text { sonucuna ulaşmıştır. }\end{array}$ \\
\hline Tsani (2010) & $1960-2006$ & Yunanistan & $\begin{array}{l}\text { Granger } \\
\text { nedensellik ve } \\
\text { VAR analizi }\end{array}$ & $\begin{array}{l}\text { Çalışmada, sanayi sektörü, taşıma } \\
\text { sektörü ve yerleşik bölgenin enerji } \\
\text { tüketimlerine göre değerlendirme } \\
\text { gerçekleştirilmiş, ekonomik büyüme ve } \\
\text { enerji tüketiminde ikili nedenselliğin } \\
\text { olmadığ1, fakat toplam enerji } \\
\text { tüketiminden reel GSYİH'ya doğru } \\
\text { nedenselliğin gerçekleştiği sonucunu } \\
\text { ulaşılmıştır. }\end{array}$ \\
\hline
\end{tabular}




\begin{tabular}{|c|c|c|c|c|}
\hline $\begin{array}{l}\text { Wong vd. } \\
\text { (2013) }\end{array}$ & $1980-2010$ & $\begin{array}{l}\text { OECD } \\
\text { ülkeleri }\end{array}$ & $\begin{array}{l}\text { Tam } \\
\text { değiştirilmiş en } \\
\text { küçük kareler } \\
\text { (FMOLS) ve } \\
\text { dinamik en } \\
\text { küçük karelere } \\
\text { (DOLS) dayalı } \\
\text { panel veri } \\
\text { testleri }\end{array}$ & $\begin{array}{l}\text { Çalışmada, OECD ülkelerini petrol } \\
\text { rezervi olanlar ve olmayanlar; enerji } \\
\text { tüketimini ise fosil yakıtlar ve } \\
\text { yenilenebilen kaynaklar olarak iki alt } \\
\text { bölüme ayırılmış, Analiz sonucunda, } \\
\text { sermaye birikimi ve fosil yakıtlar } \\
\text { ekonomik büyümeyi harekete geçirmede } \\
\text { ana faktördür ve yenilenebilen kaynaklar, } \\
\text { özellikle petrol rezervleri olmayan } \\
\text { ülkelerde reel çıtıtı düzeyine katkıda } \\
\text { bulunduğu sonucuna ulaşılmıştır. }\end{array}$ \\
\hline Omri (2013) & $1990-2001$ & $\begin{array}{l}\text { Ortadoğu ve } \\
\text { Kuzey } \\
\text { Afrika }\end{array}$ & $\begin{array}{l}\text { Panel veri } \\
\text { yöntemi }\end{array}$ & $\begin{array}{l}\text { Çalışmada, enerji tüketimi ile ekonomik } \\
\text { büyüme arasında ve CO2 emisyonu ve } \\
\text { ekonomik büyüme arasında iki yönlü } \\
\text { nedensellik ilişkisi olduğu sonucuna } \\
\text { ulaşılmıştır. }\end{array}$ \\
\hline $\begin{array}{l}\text { Jaraite vd. } \\
\text { (2015) }\end{array}$ & $1990-2012$ & $\begin{array}{l}15 \mathrm{AB} \\
\text { Ülkesi }\end{array}$ & $\begin{array}{l}\text { Panel veri, } \\
\text { zaman serileri } \\
\text { analizi }\end{array}$ & $\begin{array}{l}\text { Çalışmada, } 15 \mathrm{AB} \text { ülkesinde yenilebilir } \\
\text { enerjinin teknolojik gelişmeyi ve uzun } \\
\text { dönemde ekonomik büyümeyi } \\
\text { desteklediği, kısa dönemde ise istihdam } \\
\text { düzeyini arttırdığı sonucuna ulaşılmıştır. }\end{array}$ \\
\hline $\begin{array}{l}\text { Khawlah ve } \\
\text { Abdallah } \\
(2016)\end{array}$ & 1986-2012 & Ürdün & $\begin{array}{l}\text { Zaman serileri } \\
\text { ve } \\
\text { eşbütünleşme } \\
\text { testi }\end{array}$ & $\begin{array}{l}\text { Çalış̧a da, Reel GSYH, yenilenebilir } \\
\text { enerii tüketimi, reel brüt sabit sermaye } \\
\text { arasında uzun dönemli bir denge ilişkisi, } \\
\text { Hata düzeltme modellerinin sonuçlarına } \\
\text { göre tek yönlü bir nedensellik ilişkisinin } \\
\text { olduğu, bunun ise yenilenebilir enerji } \\
\text { tüketiminden reel GSYH'ye doğru } \\
\text { olduğu, Kısa vadede ise sermaye ve } \\
\text { yenilenebilir enerji tüketimi arasında } \\
\text { nedensellik ilişkisi olduğu sonucuna } \\
\text { ulaşılmıştır. }\end{array}$ \\
\hline $\begin{array}{l}\text { Armeanu, } \\
\text { Vintila ve } \\
\text { Gherghina } \\
\text { (2017) }\end{array}$ & 2003-2014 & $\begin{array}{l}\text { AB'ye üye } 28 \\
\text { ülke }\end{array}$ & $\begin{array}{l}\text { Panel veri } \\
\text { analizi }\end{array}$ & $\begin{array}{l}\text { Çalışmada, Yenilebilir eneriji tüketiminin } \\
\text { artmast ekonomik büyümeyi arttırdığı, } \\
\text { yenilenebilir enerjinin birincil üretiminde } \\
\% 1 \text { 1'lik artısın kişi başına GSYH' da } \\
\% 0.05-0.06 \text { oranında artışa neden } \\
\text { olduğu sonucuna ulaşılmış, Bununla } \\
\text { birlikte, panel vektör hata düzeltme } \\
\text { modeline dayanan Granger } \\
\text { nedenselliğinin sonuçları, hem kısa hem } \\
\text { de uzun vadede sürdürülebilir ekonomik } \\
\text { büyümeden başlayarak yenilenebilir } \\
\text { enerjilerin birincil üretimine doğru tek } \\
\text { yönlü bir nedensellik ilişsisinin var } \\
\text { olduğunu tespit edilmiştir. }\end{array}$ \\
\hline $\begin{array}{l}\text { Akarca ve } \\
\text { Long (1980) }\end{array}$ & $1973-1978$ & $\mathrm{ABD}$ & $\begin{array}{l}\text { Granger } \\
\text { Nedensellik } \\
\text { Testi }\end{array}$ & $\begin{array}{l}\text { Çalış̧mada, ekonomik büyüme ile enerji } \\
\text { arasında nedensellik ilişkisi olduğu } \\
\text { bulgusuna ulaşılmıştır. }\end{array}$ \\
\hline
\end{tabular}




\begin{tabular}{|c|c|c|c|c|}
\hline $\begin{array}{l}\text { Erol ve Yu } \\
\text { (1984) }\end{array}$ & $\begin{array}{c}1950-1982 \\
1950-1973\end{array}$ & $\begin{array}{l}\text { Bat1 } \\
\text { Almanya, } \\
\text { İngiltere, } \\
\text { Kanada, } \\
\text { Fransa, } \\
\text { İtalya ve } \\
\text { Japonya }\end{array}$ & $\begin{array}{l}\text { Sims Tekniği } \\
\text { ve Granger } \\
\text { nedenselliği }\end{array}$ & $\begin{array}{l}\text { Çalışmada, enerji tüketimi ve büyüme } \\
\text { ilişkisi ile enerji tüketimi ve istihdam } \\
\text { ilişkisini analiz edilmiş, hem enerji } \\
\text { tüketimi ve büyüme arasında hem de } \\
\text { enerji tüketimi ve istihdam arasında } \\
\text { önemli bir ilişki bulunamamıştır. }\end{array}$ \\
\hline $\begin{array}{l}\text { Soytaş ve } \\
\text { San (2003) }\end{array}$ & 1950-1992 & $\begin{array}{l}\text { Gelişmekte } \\
\text { olan } 10 \\
\text { piyasa ile } \\
\text { G-7 (Çin } \\
\text { veri eksikliği } \\
\text { nedeniyle } \\
\text { analiz dış1 } \\
\text { bırakılmıştır.) }\end{array}$ & $\begin{array}{l}\text { Granger } \\
\text { Nedensellik } \\
\text { Yöntemi }\end{array}$ & $\begin{array}{l}\text { Çalışmada, Türkiye, Fransa, Almanya ve } \\
\text { Japonya için nedensellik ilişkisinin enerji } \\
\text { tüketiminden ekonomik büyümeye } \\
\text { doğru olduğu, Arjantin de ise iki yönlü } \\
\text { nedensellik ilişkisi olduğu sonucuna } \\
\text { ulaşılmıştır. Bulgulara göre uzun } \\
\text { dönemde, enerji korumasının bu ülkelere } \\
\text { ekonomik zarar vereceği ifade edilmiştir. }\end{array}$ \\
\hline $\begin{array}{l}\text { Altınay ve } \\
\text { Karagöl } \\
(2004)\end{array}$ & $1950-2000$ & Türkiye & $\begin{array}{l}\text { Granger } \\
\text { Nedensellik } \\
\text { Yöntemi }\end{array}$ & $\begin{array}{l}\text { Çalışmada, } 1950-2000 \text { döneminde } \\
\text { ekonomik büyüme ile enerji tüketimi } \\
\text { arasında nedensellik ilişkisi olmadığ1 } \\
\text { sonucuna ulaşılmıştır. }\end{array}$ \\
\hline $\begin{array}{l}\text { Şengül ve } \\
\text { Tuncer } \\
\text { (2006) }\end{array}$ & $\begin{array}{l}\text { 1960-2000 } \\
\text { dönemi }\end{array}$ & Türkiye & $\begin{array}{l}\text { Toda ve } \\
\text { Yamamoto } \\
\text { gecikmesi } \\
\text { artırilmıs VAR } \\
\text { yöntemi }\end{array}$ & $\begin{array}{l}\text { Çalışmada, ticari enerji tüketiminden } \\
\text { GSYH'ye doğru işleyen tek yönlü bir } \\
\text { nedensellik ilişkisi, reel enerji fiyatları ile } \\
\text { GSYH arasında iki yönlü bir nedensellik } \\
\text { ilişkisi, reel enerji fiyatları endeksinden } \\
\text { ticari enerji kullanımına doğru işleyen tek } \\
\text { yönlü bir nedensellik ilişkisi olduğu } \\
\text { sonucuna ulaşılmıştır. }\end{array}$ \\
\hline $\begin{array}{l}\text { Erbaykal } \\
\text { (2008) }\end{array}$ & $1970-2003$ & Türkiye & $\begin{array}{l}\text { Birim kök testi, } \\
\text { Peseran } \\
\text { eşbütünleşme } \\
\text { testi }\end{array}$ & $\begin{array}{l}\text { Çalışmada, Kısa dönemde hem elektrik } \\
\text { tüketiminin hem de petrol tüketiminin } \\
\text { üzerinde pozitif ve anlamlı bir etkiye } \\
\text { sahip olduğu, uzun dönemde ise } \\
\text { ekonomik büyüme üzerinde petrol } \\
\text { tüketiminin pozitif, enerji tüketiminin ise } \\
\text { negatif etkiye sahip olduğu sonucuna } \\
\text { ulaşılmıştır. }\end{array}$ \\
\hline $\begin{array}{l}\text { Mucuk ve } \\
\text { Uysal (2009) }\end{array}$ & $1960-2006$ & Türkiye & $\begin{array}{l}\text { Birim Kök, } \\
\text { eşbütünleşme, } \\
\text { granger } \\
\text { nedensellik } \\
\text { testleri, etki- } \\
\text { tepki } \\
\text { fonksiyonlar1 } \\
\text { ve varyans } \\
\text { ayrıştırmas1 } \\
\text { yöntemleri }\end{array}$ & $\begin{array}{l}\text { Çalışmada, değişkenler arasında } \\
\text { eşbütünleşme ilişkisi bulunmuş ve } \\
\text { Granger nedenselliğin yönü enerji } \\
\text { tüketiminden ekonomik büyümeye } \\
\text { doğru olduğu ifade edilmiştir. }\end{array}$ \\
\hline Özata (2010) & $1970-2008$ & Türkiye & $\begin{array}{l}\text { Granger testi, } \\
\text { eşbütünleşme } \\
\text { testi ve vektör } \\
\text { hata düzeltme } \\
\text { modeli }\end{array}$ & $\begin{array}{l}\text { Çalışmada, reel GSMH ile enerji } \\
\text { tüketiminin eşbütünleşik oldukları ve } \\
\text { reel GSMH'dan enerji tüketimine doğru } \\
\text { tek yönlü bir Granger nedensellik ilişkisi } \\
\text { olduğu sonucuna ulaşılmıştır. }\end{array}$ \\
\hline
\end{tabular}




\begin{tabular}{|c|c|c|c|c|}
\hline $\begin{array}{l}\text { Çetin ve } \\
\text { Şeker (2012) }\end{array}$ & $1970-2009$ & Türkiye & $\begin{array}{l}\text { Johansen ve } \\
\text { Juselius } \\
\text { eşbütünleşme } \\
\text { testi ve Toda- } \\
\text { Yamamoto } \\
\text { nedensellik } \\
\text { testleri }\end{array}$ & $\begin{array}{l}\text { Çalış̧mada, enerji tüketiminin, ekonomik } \\
\text { büyüme üzerinde pozitif ve güçlü bir } \\
\text { etkiye sahip olduğu, Toda-Yamamoto } \\
\text { testine göre enerji tüketimi ile ekonomik } \\
\text { büyüme arasinda herhangi bir } \\
\text { nedensellik ilişkisi olmadığı sonucuna } \\
\text { ulaşılmıştı. }\end{array}$ \\
\hline $\begin{array}{l}\text { Uzunöz ve } \\
\text { Akçay (2012) }\end{array}$ & $1970-2010$ & Türkiye & $\begin{array}{l}\text { Johansen } \\
\text { eşbütünleşme } \\
\text { ve Granger } \\
\text { nedensellik } \\
\text { testlerini }\end{array}$ & $\begin{array}{l}\text { Çalışmada, değişkenler arasında } \\
\text { eşbütünleşme ve uzun dönem ilişkisi } \\
\text { olduğu, ekonomik büyümeden enerji } \\
\text { tüketimine doğru tek yönlü Granger } \\
\text { nedensellik ilişkisinin olduğu sonucuna } \\
\text { ulaşılmış̧ır. }\end{array}$ \\
\hline Yalta (2013) & $1950-2006$ & Türkiye & $\begin{array}{l}\text { Eşbütünleşme } \\
\text { Analizi }\end{array}$ & $\begin{array}{l}\text { Çalsşmada, enerji tüketimi ve GSYİH } \\
\text { arasında nötr bir ilişki bulunmuştur }\end{array}$ \\
\hline $\begin{array}{l}\text { Ocal ve } \\
\text { Aslan (2013) }\end{array}$ & & Türkiye & $\begin{array}{l}\text { ARDL } \\
\text { yaklaşımı ve } \\
\text { Toda- } \\
\text { Yamamoto } \\
\text { nedensellik } \\
\text { testi }\end{array}$ & $\begin{array}{l}\text { Çalışmada, Ekonomik büyümeden } \\
\text { yenilenebilir enerji tüketimine doğru tek } \\
\text { yönlü bir nedensellik ilişkisinin } \\
\text { bulunduğu sonucuna ulaşmışlardır. }\end{array}$ \\
\hline $\begin{array}{l}\text { Kalyoncu } \\
\text { vd. (2013) }\end{array}$ & $1960-2006$ & Türkiye & $\begin{array}{l}\text { Johansen } \\
\text { eşbütünleşme, } \\
\text { nedensellik ve } \\
\text { Vektör Hata } \\
\text { Düzeltme } \\
\text { modelleri }\end{array}$ & $\begin{array}{l}\text { Çalışmada, değişkenler arasında kısa } \\
\text { dönemli ilişki olmadığı ve kişi başı } \\
\text { GSYH'dan kişi başı enerji tüketimine } \\
\text { doğru uzun dönem nedensellik olduğu } \\
\text { sonucuna ulaşmışlardır. }\end{array}$ \\
\hline $\begin{array}{l}\text { Ruhul, } \\
\text { Kamrul ve } \\
\text { Shar (2014) }\end{array}$ & $1980-2011$ & $\begin{array}{l}\text { OECD } \\
\text { ülkeleri }\end{array}$ & $\begin{array}{l}\text { Panel } \\
\text { eşbütünleştirme } \\
\text { tekniği }\end{array}$ & $\begin{array}{l}\text { Çalışmada, fosil ve yenilenebilir enerji } \\
\text { kaynakları, sanayi üretimi ve ekonomik } \\
\text { büyüme arasında uzun vadeli bir denge } \\
\text { ilişkisininin olduğu, Ayrıca panel } \\
\text { nedensellik analizleri ile GSYH } \\
\text { büyümesi ile yenilenebilir enerji tüketimi } \\
\text { arasındaki tek yönlü nedenselliğin var } \\
\text { olduğu tespit edilmiştir. }\end{array}$ \\
\hline $\begin{array}{l}\text { Kazar ve } \\
\text { Kazar (2014) }\end{array}$ & $\begin{array}{l}1980-2010 \\
2005-2010\end{array}$ & Türkiye & $\begin{array}{l}\text { Panel } \\
\text { eşbütünleştirme } \\
\text { tekniği }\end{array}$ & $\begin{array}{l}\text { Çalışmada, Türkiye' de yenilenebilir } \\
\text { eneriji ile iktisadi gelişme arasındaki } \\
\text { ilişskiyi uzun dönem için 1980-2010, kısa } \\
\text { dönem için ise 2005-2010 verilerini } \\
\text { kullanılmış kısa vadede yenilenebilir } \\
\text { enerji üretimi ile ekonomik kalkınma } \\
\text { arasında çift yönlü bir nedensellik ilişki } \\
\text { bulunduğu, uzun vadede ise ekonomik } \\
\text { kalkınma sürecinin yenilenebilir eneriji } \\
\text { üretimine yol açtığı sonucuna } \\
\text { ulaşılmıştrr. }\end{array}$ \\
\hline
\end{tabular}




\begin{tabular}{|c|c|c|c|c|}
\hline $\begin{array}{l}\text { Altıntaş ve } \\
\text { Mercan } \\
(2015)\end{array}$ & $1980-2011$ & G-ll ülkeleri & $\begin{array}{l}\text { Yapisal } \\
\text { kırlmmalı panel } \\
\text { eşbütünleşme } \\
\text { ve nedensellik } \\
\text { analizleri, } \\
\text { Bootstrap } \\
\text { panel } \\
\text { nedensellik } \\
\text { testleri }\end{array}$ & $\begin{array}{l}\text { Çalışmada, kişi başı elektrik tüketiminin } \\
\% 1 \text { artmasının ekonomik büyümeyi } \\
\% 21.4 \text { oranında arttırdığı sonucuna } \\
\text { ulaşmıslardır. Tüm ülkelerin birlikte } \\
\text { incelendiği hata düzeltme modeline } \\
\text { dayalı panel nedensellik testi sonuçlarına } \\
\text { göre ise, elektrik tüketimi ile ekonomik } \\
\text { büyüme arasında çift yönlü kısa dönem } \\
\text { Granger nedensellik ilişkisis olduğu ve } \\
\text { incelenen ülke grubu için geri besleme } \\
\text { (feedback) hipotezinin geçerli olduğu } \\
\text { sonucuna ulaşmışlardır. }\end{array}$ \\
\hline Tatlı (2015) & $1981-2013$ & Türkiye & $\begin{array}{l}\text { ARDL sinır } \\
\text { testi yöntemiyle }\end{array}$ & $\begin{array}{l}\text { Çalş̧̧ada, uzun dönemde ekonomik } \\
\text { büyüme ile toplam enerji tüketimi, } \\
\text { gayrisafi sabit sermaye oluşumu ve } \\
\text { istihdam arasinda pozitif bir ilişki olduğu } \\
\text { tespit edilmiştir. Uzun dönemde } \\
\text { ekonomik büyüme üzerinde en büyük } \\
\text { etkiye sahip olan değişkenin toplam } \\
\text { enerji tüketimi olduğu, uzun dönemde } \\
\text { Türkiye'de toplam enerii tüketiminin } \\
\text { ekonomik büyüme üzerinde anlamll bir } \\
\text { düzeyde etkili olduğunu ve ekonomik } \\
\text { büyümenin toplam enerji tüketimine } \\
\text { bağlı olduğu sonucuna ulaşlmısı̧tır. }\end{array}$ \\
\hline
\end{tabular}

*Tablo yazarlar tarafindan oluşturulmuştur.

\section{YÖNTEM}

Analiz döneminin uzunluğu dönem içerisinde meydana gelen olayların bir zaman serisi değişkenini güçlü ölçülerde etkilemesine yol açmaktadır. Özellikle siyasi kararlar, doğal afetler, küresel çatışmalar vb. gibi nedenlerden dolayı zaman serisi değişkeninde bir veya daha fazla yapısal değişim (kırılma) görülebilmektedir. Bu kırılmalar dikkate alınmadan yapılacak birim kök testlerinde gerçekte durağan olan bir değişkenin birim kök içerdiği sonucuna ulaşılabilmektedir. Bunun sonucu olarak da sahte regresyon problemi ile karşılaşılmaktadır. Böylece değisskenler arasında anlamlı bir ilişki olmamasına rağmen yüksek bir $\mathrm{R}^{2}$ değeri bulunurken, katsayıların t-istatistikleri anlamlı görünebilmektedir. $\mathrm{Bu}$ sonuçlarla birlikte analizden elde edilen bilgiler güvenilirliklerini yitirmektedir.

$\mathrm{Bu}$ nedenlerden dolayı eldeki çalışmada tek kırılmayı içsel olarak dikkate alan Zivot ve Andrews (ZA, 1992) birim kök testi kullanılacaktır. Daha sonra tek kırrlmayı dikkate alan Gregory ve Hansen (GH, 1996) eşbütünleşme testi ile değişkenler arasında eşbütünleşme ilişkisi olup olmadığı araştırılacaktır. Son olarak eşbütünleşme ilişkisi bulunması durumunda uzun dönem katsayıları elde etmek için Dinamik EKK (Dynamic OLS, Stock ve Watson, 1993), Tam Değiştirilmiş EKK (Fully-Modified OLS, Hansen, 1992) ve Kanonik Eşbütünleşme Regresyonu (Canonical Cointegrating Regression, Park 1992) tahmincileri kullanılacaktır. 


\subsection{Zivot ve Andrews (1992)}

Klasik birim kök testlerinin zayıf yanı kırilmaları dikkate almamasından kaynaklanan sorunlardır. İlk defa Perron (1989) tarafindan kırılmanın dışsal olarak belirlendiği birim kök testini önermektedir. Fakat bu testin de eksik yönleri bulunmaktadır. Örneğin, Perron (1989) testi uygulanırken kırılma tarihinin önceden belirlenmesi gerekmektedir. Bazı analizlerde keskin bir şekilde bu kırılma tarihi belirlenememektedir. Dolayısıyla yanlış belirlenen kırılma tarihi, birim kök testinin sonucunu da etkilemektedir. Literatürdeki bu eksikliği gören ZA, kırılmanın test stratejisi içerisinde belirlendiği yeni bir birim kök testini literatüre önermektedir. Bu test ile birlikte kırılma tarihinin önsel olarak bilindiği varsayımı ortadan kalkmaktadır. ZA test modellerini oluştururken Perron (1989) test denklemlerinden yararlanmışlardır.

Aşağıda ZA testinin veri yaratma süreci gösterilmektedir:

$$
y_{t}=\delta Z_{t}+e_{t} \text { ve } e_{t}=\beta e_{t-1}+\varepsilon_{t}
$$

Bu testin başlangiç noktası Eşitlik 1'deki gibi bir veri yaratma sürecinden oluşmaktadır. Daha sonra bu test aşağıdaki gibi ADF prensibine göre oluşturulmaktadır:

ZA yönteminin test stratejisinde tahmin edilen model:

$$
\Delta y_{t}=\hat{\delta} \Delta Z_{t}+\emptyset y_{t-1}+\sum_{j=1}^{k} \beta_{j} \Delta y_{t-j}+\varepsilon_{t}
$$

Eşitlik 2'deki modelde $Z_{t}$ dişsal değişkenler vektörüdür ve $Z_{t}$ 'nin çeşitli oluşturulma biçimlerine bağlı olarak ZA testi ortaya çıkmaktadır.

ZA testinde $Z_{t}$ dişsal değişkenler vektörü tek kırılmayı içerecek biçimde aşağıdaki gibi tanımlanmaktadır:

- $\quad Z_{t}=\left[1, t, D_{t}\right]$ : sabitte tek kirlma (Model A).

Buradat $\geq T_{B}+1$ için $D_{t}=1$, diğer durumlar için 0 değerini almakta; $T_{B}$ ise yapısal kırılmanın zamanını belirtmektedir.

- $Z_{t}=\left[1, t, D_{t}, D T_{t}\right]$ : sabitte ve trende tek kırlma (Model C).

Burada $t \geq T_{B}+1$ için $D T_{t}=t-T_{B}$, diğer durumlarda ise 0 değeri almakta; ayrıca, 2 numaralı eşitlikte $\sum_{j=1}^{k} \beta_{j} \Delta y_{t-j}$ terimi ADF yaklaşımında otokorelasyon sorununu çözmek için regresyon modeline katılmaktadır. Burada, karşımıza optimal gecikme uzunluğu belirleme sorunu çıkmaktadır. Perron'a (1989) göre $k$ 'nın optimal sayısına karar verebilmek için genelden özele yaklaşımından yararlanılması gerekmektedir. En çok sayıda gecikme ile başlanarak regresyonlar tahmin edilir ve kritik değere göre sıfır hipotezinin reddedildiği ilk gecikmede durulur. Böylece uygun gecikme sayısı belirlenir (Ng ve Perron, 1995:276-278). 
Serinin durağan olup-olmadı̆̆ını belirlemek için tanımlanan sıfır ve alternatif hipotezler şu şekildedir:

$H_{0}: \emptyset=0$, birim kök vardır (seri birim kök içermektedir).

$H_{1}: \emptyset<0$, birim kök yoktur (seri durağandır).

Yapısal kırılmanın olmadığı durumda, hipotez testi için kullanılan test istatistiği aşağıdaki gibidir:

$$
\tau=t-\operatorname{stat}(\widehat{\varnothing})=\frac{\widehat{\varnothing}}{\operatorname{sh}(\widehat{\varnothing})}
$$

Burada, $\widehat{\varnothing}$ Eşitlik 2'de verilen modelin EKK yönteminden elde edilen parametre, sh ise bu parametreye ilişkin standart hatayı göstermektedir.

Yapısal kırılmanın olduğu durumda ise, ADF tipi test stratejini kullanan ZA için, Eşitlik 2'de verilen modelde, tek taraflı t-istatistiğini minimize eden $\tau$ değeri seçilmektedir:

$$
t_{\widehat{\emptyset}^{i}}\left[\hat{\tau}_{i n f}^{i}\right]={ }_{\tau \in \Lambda}^{i n f} t_{\widehat{\emptyset}^{i}}(\tau), i=A, C
$$

Burada $\Lambda \in 0,1)$ 'dir. $T_{B}$ kırılma zamanı, olası kırılma noktaları için en küçük (negatif) birim kök t-istatistiğini veren nokta olarak seçilmektedir (Çă̆lar, 2015:16-19).

\subsection{Gregory ve Hansen (1996) Testi}

GH (1996), Engle ve Granger (EG, 1987) eşbütünleşme testine yap1sal kırılmayı temsil eden kukla değişken ekleyerek yeni bir eşbütünleşme testi önermektedirler. Bazı ampirik uygulamalarda araştırmacılar bu testten yararlanmışlardır. Fakat durağan olmayan serilerin doğrusal kombinasyonunun durağan olma ihtimalini göz önünde bulundurarak çalışmalarını gerçekleştirmişlerdir. Böylece "Bu seriler eşbütünleşiktir" biçiminde oluşturulan alternatif hipotez kabul edip edemeyeceklerini anlamaya çalışmışlardır.

Ancak standart eşbütünleşme testlerinin zayıf kaldığı bir nokta vardır: Değişkenlerin doğrusal kombinasyonu örneklem boyunca bilinmeyen bir noktada değişime uğramış olabilir. İşte standart eşbütünleşme testleri bunu gözden kaçırmaktadır. GH (1996), söz konusu zayıflı̆̆ı ortadan kaldırmak için EG (1987) testinde açıklanan modele kırılmayı temsil eden kırılma kuklası eklenmesini önermektedir. Bu testin diğer bir önemli özelliği ise kırılma noktası önceden bilinmemektedir. Yani kırılma test stratejisi içerisinde içsel olarak belirlenmektedir. GH (1996) testi, düzeyde (C), trend de (C/T) ve rejimde $(\mathrm{C} / \mathrm{S})$ tek kırılmaya izin verecek biçimde üç farklı modelden oluşmaktadır:

$$
y_{t}=\beta_{1}+\beta_{2} \gamma_{1 \tau}+\theta_{1} y_{2 \tau}+e_{t}, t=1, \ldots, n
$$




$$
\begin{aligned}
& y_{t}=\beta_{1}+\beta_{2} \gamma_{1 \tau}+b t+\theta_{1} y_{2 \tau}+e_{t}, t=1, \ldots, n \\
& y_{t}=\beta_{1}+\beta_{2} \gamma_{1 \tau}+\theta_{1} y_{2 \tau}+\theta_{2} y_{2 \tau} \gamma_{1 \tau}+e_{t}, t=1, \ldots, n
\end{aligned}
$$

Eşitlik 5, 6 ve 7'deki modellerde, $\gamma_{1 \tau}$ kırılma kuklasını temsil etmektedir ve aşağıdaki gibi tanımlanmaktadır:

$\gamma_{1 \tau}=\left\{\begin{array}{l}0, t \leq[n \tau] \\ 1, t>[n \tau]\end{array}\right\}$

Burada $\tau$ yapısal kırılma noktasını göstermekte ve aynı zamanda bilinmemektedir. Ayrıca, $n \tau$ sayısının tamsayı değeri olan $[n \tau]$ gösterimi yapısal kırılma noktasının tamsayı olmasını güvence altına almaktadır. Öte yandan söz konusu testte sıfir hipotezi "Eşbütünleşme yoktur" biçiminde oluşturulmaktadır. Hipotezlerin geçerliliğini sınamak için $A D F^{*}, Z_{t}^{*}, Z_{\alpha}^{*}$ olmak üzere üç farklı test istatistiği hesaplanmaktadır (Çağlar ve Mert, 2017; 27-29).

\section{VERIILER VE AMPİRİK BULGULAR}

Bu çalışma, Türkiye'de enerji tüketiminin büyüme üzerindeki etkilerini ortaya çıkararak politika yapıcılara öneriler getirmeyi planlamaktadır. Bu amaçla ulaşılan en güncel veriler Dünya Bankası (World Bank) veri tabanından elde edilmektedir. Türkiye'de 1960-2014 yılları arasında, kişi başına reel gayri safi yurt içi hasıla (2010 sabit fiyatları ile \$ cinsinden, GSYH) ve enerji tüketimi (kişi başına kg petrol eşdeğeri, EC) değişkenleri kullanılacaktır. Aşağıda verilere ait tanımlayıc istatistikler bulunmaktadır.

\section{Tablo 3: Tanımlayıcı İstatistikler}

\begin{tabular}{|l|l|l|l|l|l|}
\hline Değişkenler & Ortalama & Medyan & En az & En çok & Standart Sapma \\
\hline GSYH & 6345.18 & 6039.71 & 2996.48 & 11245.78 & 2365.22 \\
\hline EC & 907.64 & 907.14 & 384.34 & 1561.83 & 348.12 \\
\hline
\end{tabular}

Tablo 3'de 1960-2014 yılları arasında Türkiye'de ortalama kişi başına düşen milli gelir 6345.18 \$ivarındayken, Türkiye'nin enerji tüketiminin ortalamas1 ise 907.64\$ seviyelerindedir. Ayrıca kişi başına düssen milli gelir y1llar itibari ile en az olarak 2996.48 iken en çok $11245.78 \$$ olmaktadır. Buna benzer veri özelliği gösteren enerji tüketiminde de en az 384.34 iken en çok ise $1561.83 \$$ düzeyinde olduğu görülmektedir. Analiz öncesinde verilerin doğal logaritması alınmıştır ve analize bu şekilde devam edilmiştir. 


\section{Grafik 1: Büyüme ve Enerji Tüketimi.}

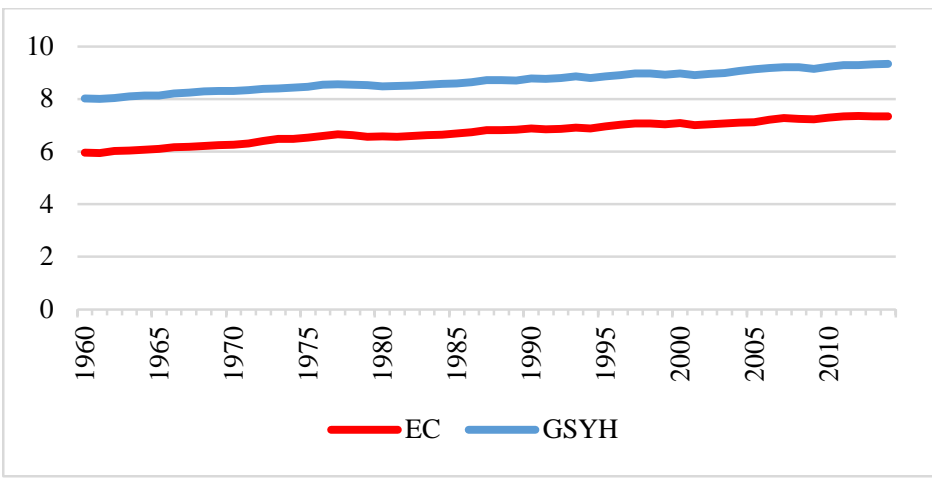

Yukarıda değişkenlere ait zaman yolu grafiği gösterilmektedir. Ekonometrik analize geçmeden önce bu grafiğe bakılarak çıarımlar yapılabilmektedir. Örneğin GSYH ve EC değişkenlerinin artış trendinde oldukları görülmektedir. Ayrıca çalışmanın motivasyonunu oluşturan, her iki değişkenin de birlikte hareket ettiği (co-movement) görülmektedir. Dolayısıyla bu iki değişken arasında eşbütünleşme ilişkisi olabileceği düşünülmektedir. Eğer GSYH ve EC arasında eşbütünleşme ilişkisi bulunursa uzun dönem katsayıları elde edilecek olup Türkiye ekonomisinin enerji politikalarına dair öneriler sunulacaktır. Eşbütünleşme ilişkisinin varllğını sorgulamadan önce serilerin aynı dereceden bütünleşik olup olmadığının belirlenmesi gerekmektedir. Bunun için aşağıldaki Tablo 4'de birim kök test sonuçları gösterilmektedir.

\section{Tablo 4: Birim Kök Test Sonuçları}

\begin{tabular}{|c|c|c|c|c|c|c|}
\hline \multirow[b]{3}{*}{ Değişkenler } & \multicolumn{2}{|c|}{ Kurlmayn Dikekate Almayan } & & \multicolumn{3}{|c|}{ Kinlmay Dikkate Alan } \\
\hline & \multicolumn{2}{|c|}{$\mathrm{ADF}$} & & \multicolumn{3}{|c|}{ ZA } \\
\hline & $\begin{array}{c}\text { Sabit } \\
\text { Modeli }\end{array}$ & $\begin{array}{c}\text { Sabit ve } \\
\text { Trend } \\
\text { Modeli }\end{array}$ & $\begin{array}{c}\text { Sabit } \\
\text { Modeli }\end{array}$ & $\begin{array}{c}\text { Kirilma } \\
\text { Tarihi }\end{array}$ & $\begin{array}{c}\text { Sabit ve } \\
\text { Trend } \\
\text { Modeli }\end{array}$ & $\begin{array}{l}\text { Kirilma } \\
\text { Tarihi }\end{array}$ \\
\hline GSYH & -0.555 & -3.090 & -4.037 & 1979 & -4.755 & 1979 \\
\hline $\mathrm{EC}$ & -1.359 & -2.312 & -3.717 & 1971 & -4.445 & 1979 \\
\hline$\Delta G S Y H$ & $-7.553^{*}$ & $-7.580^{*}$ & $-7.773^{*}$ & 1977 & $-7.826^{*}$ & 2003 \\
\hline$\Delta E C$ & $-7.042^{*}$ & $-7.177^{*}$ & $-7.666^{*}$ & 1978 & $-7.619^{*}$ & 1978 \\
\hline
\end{tabular}

Not:: ADF, Agumented Dickey Fuller $(1979,1982)$ birim kök testini ve ZA, Zivot ve Andrews (1992) kır1lmalı birim kök testini ifade etmektedir. Gecikme uzunluğu belirlenirken Schwarz bilgi kriterine göre karar verilmiștir. ADF kritik değerleri, sabit modeli için; -3.557 (\%1), -2.917 (\%5), -2.596 (\%10), sabit ve trend modeli için; -4.137 (\%1), -3.495 (\%5), -3.177 
(\%10), ZA kritik değerleri, sabit modeli için; -5.34 (\%1), - 4.80 (\%5), -4.58 (\%10), sabit ve trend modeli için; -5.57 (\%1), $5.08(\% 5),-4.82(\% 10)$ olarak değerlendirilmektedir.

Tablo 4 incelendiğinde, kırılmayı dikkate almayan ADF birim kök testine göre GSYH ve EC değişkenlerinin hem sabitli modelde hem de sabit ve trend modelinde birim kök taşıdığı gözlemlenmektedir. Diğer taraftan kırılmayı dikkate alan ZA birim kök testi sonuçları incelendiğinde de ADF testi ile tutarlı sonuçlar elde edildiği görülmektedir. Her iki değişkenin de birinci dereceden farkı alınarak işlemlere devam edildiğinde, yine tutarlı sonuçlar elde edilerek iki değişkenin de birinci dereceden durağan olduğu belirlenmektedir. Yapısal kırılmalı birim kök analizinin önemli bir bulgusu olan kırılma tarihi değişkenlerin düzey değerleri için 1971 ve 1979 ylllarını göstermektedir. Bu dönemde yaşanan iki petrol krizi sonucu petrol ihraç eden ülkelerin petrol fiyatlarının aşırı artırması ve bazı ülkelere kota koyulmasının bir nedeni olduğu düşünülmektedir. GSYH ve EC değişkenlerinin birinci dereceden birim kök taşıdığı sonucuna ulaştıktan sonra yapısal kırılmayı dikkate alan GH eşbütünleşme testine geçilmektedir. Bu sonuçlar Tablo 3’te gösterilmektedir:

\section{Tablo 5: GH (1996) Test Sonuçları}

\begin{tabular}{cccccccc}
\hline Test & Model & $A D F^{*}$ & $T B$ & $Z_{t}^{*}$ & $T B$ & $Z_{\alpha}^{*}$ & $T B$ \\
\hline \multirow{2}{*}{ GH } & $\mathrm{C}$ & $-4.535^{* * *}$ & 1971 & $-4.551^{* * *}$ & 1971 & -31.775 & 1971 \\
& $\mathrm{C} / \mathrm{S}$ & -4.492 & 1971 & -4.506 & 1971 & -31.350 & 1971 \\
\hline
\end{tabular}

* 0.10 yanılma düzeyinde anlamlıdır; kritik değerler GH (1996) çalışmasından alınmıştır.

Tablo 5 incelendiğinde, düzeyde kırrlmanın olduğu $\mathrm{C}$ modeli için $A D F^{*}$ ve $Z_{t}^{*}$ test istatistiklerine göre eşbütünleşmenin olmadığını söyleyen sıfir hipotezi $\% 10$ anlamlılık düzeyinde reddedilmektedir. Dolayısıyla bu test istatistiklerine göre GSYH ve EC değişkenleri arasında bir eşbütünleşme ilişsisinin varlığından söz edilebilmektedir. Çalışmamız da, Kraft ve Kraft (1978)'in öncü olarak kabul edilen bu çalsşması, Yu ve Huwang (1984), Hwang ve Gum (1992, Stern (1993), Masih ve Masih (1996), Cheng ve Lai (1997), Aqeel ve Butt (2001), Lee ve Chang (2005), Mahadevan ve Asafu-Adjaye (2007), Odhiambo (2009), Mucuk ve Uysal (2009), Özata (2010), Çetin ve Şeker (2012), Uzunöz ve Akçay (2012), Ocal ve Aslan (2013), Altıntaş ve Mercan (2015)'nın çalışmalarıyla benzer sonuçlara ulaşılmışıtır.

Diğer taraftan rejimde bir kırlmanın olduğu C/S modelinde bütün test istatistikleri eşbütünleşmenin olmadığını söyleyen sıfır hipotezi için kabul edilmektedir. $A D F^{*}$ ve $Z_{t}^{*}$ test istatistiklerinin güç ve boyut özellikleri incelendiğinde düzeyde kırılmanın olduğu model dikkate alınarak analize devam edilecektir. Ayrıca kırılma tarihine dikkat edilirse, dünyanın enerji fiyatlarında yüksek oranda artış yaşandığı yıllar olduğu dikkat çekmektedir. $\mathrm{Bu}$ iki değişken arasında eşbütünleşme ilişkisinin olduğu belirlendikten sonra 
uzun dönem katsayıları elde edebilmek için üç farklı tahminciden yararlanılacaktır. Bunlardan birincisi DOLS, ikincisi FMOLS ve üçüncüsü ise CCR tahmincileridir. Uzun dönem katsayıların tahmincilerine göre hassasiyet gösterip göstermediğini anlamak için üç farklı tahminci kullanılmaktadır. Aşağıdaki 8 numaralı denklemde tahmin edilecek model ve Tablo 6'da tahmin sonuçları gösterilmektedir:

$G S Y H_{t}=\beta_{0}+\beta_{1} E C+u_{t}$

\section{Tablo 6: Tahmin Sonuçları}

\begin{tabular}{lcccc}
\hline Bağımlı Değişken: GSYH & Katsayı & Standart Hata & T-oranı & $P$ değeri \\
\hline DOLS & & & & \\
EC & $1.020^{*}$ & 0.022 & 47.023 & 0.000 \\
Sabit & $1.921^{*}$ & 0.135 & 14.258 & 0.000 \\
FMOLS & & & & \\
EC & $1.0238^{*}$ & 0.021 & 48.973 & 0.000 \\
Sabit & $1.817^{*}$ & 0.131 & 13.905 & 0.000 \\
CCR & & & & \\
EC & $1.039^{*}$ & 0.022 & 47.728 & 0.000 \\
Sabit & $1.812^{*}$ & 0.134 & 13.565 & 0.000 \\
\hline
\end{tabular}

* işareti tahmincilerin 0.01 yanılma düzeylerinde anlamlı olduğunu göstermektedir. Akaike gecikme uzunluğu 3 olarak seçilmiştir.

Tablo 6 incelendiğinde, enerji tüketiminin uzun dönem tahmincilere karş1 duyarsız olduğu görülmektedir. Çünkü bütün tahminciler neredeyse aynı değerdedir. Buradan önemli bir sonuç çıkartılabilir. Bütün tahmincilerden elde edilen katsayıların hemen hemen aynı olması bunlardan hangisiyle yola çıkılacak olursa olsun önerilecek politikaların da birbirlerine yakın olacağını göstermektedir. Yukarıda değinilen üç tahminciden biri olan DOLS tahminci rastgele seçilirse, Türkiye'de enerji tüketiminde meydana gelebilecek $\% 1$ 'lik bir artış ekonomik büyümeyi \%1.2 gibi bir oranda arttıracağı söylenebilmektedir.

Ekonomik büyüme bir yıldan diğer ylla üretim miktarındaki artış olarak değerlendirilmektedir. Türkiye üretimde $\% 70$ 'lere varan oranda ithalata bağımlı bir ülke olarak hammadde ithalatçısıdır, ithal ettiği petrol ve doğalgaz ile birlikte kendi ürettiği kömürü elektrik enerjisine çevirerek gereksinim duyduğu enerjiyi elde etmekte ve bunun da bir bölümünü üretimde, bir bölümünü tüketimde kullanmaktadır. Böylece enerji tüketimi artarken üretim 
ve ona bağlı olarak büyüme gerçekleşmektedir. Bu sonuçlarda dikkat edilmesi gereken önemli bir nokta vardır: Türkiye'de enerji ithalatına yukarda da belirtildiği gibi dışa bağımlılık vardır. Sürekli büyümenin hedeflenmesi için olası bir enerji dalgalanmalarından en az hasar alacak şekilde politikalar gerçekleştirilmelidir. Tüketimde enerji çeşitliliğinin oluşturulması Türkiye için önem arz etmektedir.

\section{Sonuç}

Çalışmada enerji tüketiminin büyüme üzerine etkileri araştırılmıştır. Dolayısıyla Türkiye verileri ile büyümeyi temsil etmesi için doğal logaritması alınmış gsyh ve enerji tüketimi değişkenleri kullanılmıştır. Literatürdeki çalışmalar bugün açısından bakıldığında güncel olmayan verilerle yapılmış göründüklerinden bu çalışma güncel verilerle kırılmaların dikkate alınarak analiz edilmiş bir çalışma olarak literatürü zenginleștirmiştir. Bu amaçla analize klasik birim kök testi olan ADF yaklaşımıyla birlikte kırılmaları dikkate alan ZA birim kök testi ile başlanmış, her iki teste göre de değişkenlerin birim kök özelliği taşıdığı görülmüsş ve daha sonra da serilerin grafiği incelenerek onların uzun dönemde birlikte hareket ettikleri saptanmıstır. $\mathrm{Bu}$ birlikteliği ekonometrik olarak gösterebilmek için yapısal kırılmayı dikkate alan GH eşbütünleşme yaklaşımı kullanılmıştır. Bu yaklaşım sonucuna göre ekonomik büyüme ile enerji tüketimi arasında bir eşbütünleşme ilişkisi olduğu sonucuna ulaşılmıştır. Yapısal kırılmalı birim kök analizinin önemli bir bulgusu olan kırılma tarihleri değişkenlerin düzey değerleri için 1971 ve 1979 yılları olarak belirlenmiştir. Bu tarihlerdeki kırılmanın nedeninin; Türkiye ekonomisinde, 1929 bunalımının izlerini taşıyan yıllarla birlikte 1940-1949 II. Dünya savaşının yaşandığı dönem, 1953-1959 dönemlerinde ve 1968'den sonraki yıllarda ortaya çıkan büyük oranlı fiyat artışlarının özellikle 1970'li yıllarda II. Dünya Savaşı sonrası dönemde görülen en yüksek oranların bile üzerine çıkması, 1970’li yıllarda kurulan yeni sanayi kuruluşlarının dışa bağımlılığı ve beraberinde getirdiği petrole bağımlılığın artışı olgusu, Dünyayı ve ilk olarak özellikle gelişmiş ülkeleri etkiyen I.petrol krizi ve II. İkinci petrol krizlerinin olduğu düşünülmektedir. Daha sonra uzun dönem katsayı tahminlerini elde edebilmek için literatürde sıkça kullanılan tahmincilerden DOLS, FMOLS ve CCR kullanılmıştır. Bu üç tahmincinin de hemen hemen aynı sonucu verdiği gözlemlenmiştir. DOLS sonuçları incelendiğinde enerji tüketiminin büyümeyi \%1.2 dolaylarında arttırdığı sonucuna ulaşılmıştır. Dolayısıyla enerji tüketiminin herhangi bir nedenle artmasının büyümeyi pozitif olarak tetikleyeceği sonucuna ulaşılmışır.

Analiz sonuçları genel olarak değerlendirildiğinde, Türkiye'de kısa dönemde de olsa enerji tüketimini azaltacak politikaların ekonomik büyümeyi çok olumsuz etkileyeceği öngörülebilir. Öte yandan Türkiye enerji konusunda yüksek oranda ithalata bağımlı bir ülke özelliği gösterdiği için iç kaynakları enerjiye dönüştürecek teknolojilerin desteklenmesi kaçınılmazdır. Türkiye’de 
enerji talebi yalnızca yüksek değildir, onun yanı sıra daha da yükselerek artış trendindedir. $\mathrm{Bu}$ nedenle kamuoyuna, enerji tüketiminde israfinın azaltılmasının önemini anlatma doğrultusunda çaba gösterilmesi yararlı olur. Ayrıca enerji tüketiminin farklı türlerden oluşturulması büyüme hedefleri için önemli olduğu söylenilebilir. Böylece enerji kaynaklarının gelişimine ve yenilikçi projelere daha fazla kaynak ayrılarak enerji tüketiminin sürdürülebilirliğine bir katkı sağlanabilir. 


\section{Kaynakça}

Altınay, G. \& Karagöl, E. (2004). Structural Break, Unit Root, and The Causality Between Energy Consumption and GDP in Turkey, Energy Economics, 26, 985-994.

Altıntaş H. \& Mercan M. (2015). Elektrik Tüketimi ve Ekonomik Büyüme İlişkisi: G-ll Ülkeleri Örneğinde Panel Eşbütünleşme ve Nedensellik Uygulamas1, http://eds.a.ebscohost.com/eds/pdfviewer/pdfviewer?sid $=$. 318-348,

Akarca, A.T. \& Long T.V. (1980), On the Relationship Between Energy and GNP: A Reexamination, Journal of Energy and Development, 5, 326331.

Armeanu, D. Ş., Vintilă, G., \& Gherghina, Ş. C. (2017), Does Renewable Energy Drive Sustainable Economic Growth? Multivariate Panel Data Evidence for EU-28 Countries, Energies, 10(3), 381.

Aqeel, A. \& Butt M. S. (2001), The Relationship Between Energy Consumption and Economic Growth in Pakistan, Asia-Pacific Development Journal, 8(2), 101-110.

Belke, A., C. Dreger \& F. Haan (2010). Energy Consumption and Economic Growth-New Insights into the Cointegration Relationship, Discussion Papers of DIW Berlin 1017, DIW Berlin, German Institute for Economic Research.

Burbridge, J. \& Harrison A. (1984), Testing for the Effects of Oil-Price Rises using Vector Autoregressions, International Economic Review, 25(2), 459-484.

Cheng, S. \& Lai T. (1997). An Investigation of Cointegration and Causality Between Energy Consumption and Economic Activity in Taiwan Province of China, Energy Economics, 19, 435-444.

Çağlar, A. E. (2015). Yapısal Kırılmalı Birim Kök Testlerinin Küçük Örneklem Özelliklerinin Karşısştırılması. Pamukekale Üniversitesi Sosyal Bilimler Enstitüsü Yüksek Lisans Teri, Denizli.

Çağlar, A., E. , Mert, M . (2017). Türkiye'de Çevresel Kuznets Hipotezi ve Yenilenebilir Enerji Tüketiminin Karbon Salımı Üzerine Etkisi: Yapısal Kırılmalı Eşbütünleşme Yaklaşımı. Yönetim ve Ekonomi: Celal Bayar Üniversitesi İktisadi ve İdari Bilimler Fakültesi Dergisi, 24 (1), 21 38. DOI: $10.18657 /$ yonveek.307485.

Çetin, M. \& Şeker F. (2012). Enerji Tüketiminin Ekonomik Büyüme Üzerindeki Etkisi: Türkiye Örneği, Uludă̆ Üniversitesi İIBF Dergisi, 31(1), 85-106. 
Dickey, D. A. \& Fuller, W. A. (1979). Distribution of the Estimators for Autoregressive Time Series With a Unit Root, Journal of the American Statistical Association, 7(4). 427-431.

Dickey, D. A. \& Fuller, W. A. (1981). Likelihood Ratio Statistics for Autoregressive Time Series with a Unit Root, Econometrica, Journal of the Econometric Society, 49(4), 1057-1072.

Dünya da ve Türkiye de Enerji ve Tabi Kaynaklar Görünümü, http://enerji.gov.tr/File/?path=ROOT $\% 2 \mathrm{f} 1 \% 2 \mathrm{fD}$ ocuments $\% 2 \mathrm{fE}$ nerij $\% 20 \mathrm{ve} \% 20$ Tabii $\% 20$ Kaynaklar $\% 20 \mathrm{G} \% \mathrm{c} 3 \% \mathrm{~b} 6 \mathrm{r} \% \mathrm{c} 3 \% \mathrm{bcn} \% \mathrm{c} 3$ \%bcm\%c3\%bc\%2fSayi 15.pdf (Erişim Tarihi: 10/05/2017).

Engle, R. F. \& Granger, C. W. J. (1987). Cointegration and Error-Correction: Representation, Estimation and Testing, Econometrica, 66, 251-276.

Erbaykal, E. (2008), Disaggregate Energy Consumption and Economic Growth: Evidence from Turkey, International Research Journal of Finance and Economics, 20, 172-179.

Erol, Ü. \& Yu E. H. S. (1987), On the Causal Relationship Between Energy and Income for Industrialized Countries, Journal of Energy and Development, 13, 113-122.

Glasure, Y. U. (2002), Energy and National Income in Korea: Further Evidence on the Role of Omitted Variables, Energy Economics, 24, 355-365.

Gregory, A. W. \& Hansen, B. E. (1996). Residual-Based Tests for Cointegration in Models with Regime Shifts, Journal of Econometrics, 70, 99-126.

Hamilton, J. D. (1983), Oil and the Macroeconomy since World War II, The Journal of Political Economy, 91(2), 228-248.

Hwang D. B. K. \& Gum B. (1992), The Causal Relationship Between Energy and GNP: The Case of Taiwan, Jornal of Energy and Development, 16(2), 219-226.

İKV (2004). Avrupa Birliği’nin Enerji ve Ulaştırma Politikaları ve Türkiye'nin Uyumu, İktisadi Kalk:mma Vakfi Yaymlar, Aralı, İstanbul, 159.

Jaraite j., Karumi A., Kazukauskas A. \& Kazukauskas P. (2015), Renewable Energy Policy, Economic Growth and Employment in EU:Gain without Pain, CERE Working Paper-7, 130.

Kalyoncu, H., Gürsoy, F. \& Göcen, H. (2013). Causality Relationship between GDP and Energy Consumption in Georgia, Azerbaijan and Armenia. International Journal of Energy Economics and Policy, 3(1), 111117. 
Kar, M. \& Kınık E. (2008). Türkiye'de Elektrik Tüketimi Çeşitleri ve Ekonomik Büyüme Arasındaki ilişkinin Ekonometrik Bir Analizi, Afyon Kocatepe Üniversitesi İ. İ. B. F. Dergisi, 10(2).

Karagöl E., Kavaz İ., Kaya S. \& Özdemir B. Z. (2017), Türkiye’nin Milli Enerji ve Maden Politikas1, haziran, 203.

Kazar G. \& Kazar A. (2014), The Renewable Energy Production-Economic Development Nexus, International Journal of Energy Economics and Policy, 4(2), 312-319.

Khawlah A. A. \& Abdallah S. (2016), Renewable Energy Consumption, CO2 Emissions And Economic Growth: A Case of Jordan, International Journal of Business and Economics Research, 5(6), 217-226.

Kraft, J. \& A. Kraft. (1978). On the Relationship Between Energy and GNP, Journal of Energy and Development, 3, 401-403.

Lee, Chien C. \& Chang C. P. (2005), Structural Breaks, Energy Consumption and Economic Growth Revisited: Evidence from Taiwan, Energy Economics, 27, 857-872.

Mallick, H. (2007). Does Energy Consumption Fuel Economic Growth in India?, Centre For Development Studies, Working Paper No. 388, 1-61.

Masih, A. M.M. \& Masih R. (1996), Energy Consumption, Real Income and Temporal Causality: Results From a Multi-Country Study based on Cointegration and Error-Correction Modelling Techniques, Energy Economics, 18(3), 165-183.

MFA, Türk Ekonomisinin Genel Görünümü, http://www.mfa.gov.tr/turkekonomisindeki-son-gelismeler.tr.mfa, (Erişim tarihi, 05/04/2017).

MFA, Türkiye'nin Enerji Profili ve Stratejisi, http://www.mfa.gov.tr/turkiye nin-enerji-stratejisi.tr.mfa, (Erişim tarihi, 05/04/2017).

Mahadevan, R. \& Asafu-Adjaye J. (2007), Energy Consumption, Economic Growth and Prices: A Reassesment using Panel VECM fro Developed and Developing Countries, Energy Policy, 35, 2481-2490.

Mucuk, M. \& Uysal, D. (2009). Türkiye Ekonomisinde Enerji Tüketimi ve Ekonomik Büyüme, Maliye Dergisi, 157, 105-115.

Ng, S. \& Perron, P. (1995). Unit Root Tests in ARMA Models with Data Dependent Methods for the Selection of the Truncation Lag, Journal of the American Statistical Association, 90(429), 268-281. 
Ocal, O., \& Aslan, A. (2013). Renewable Energy Consumption Economic Growth Nexus In Turkey. Renewable and Sustainable Energy Reviews, 28, 494-499.

Odhiambo, N. M.(2009), Electricity Consumption and Economic Growth in South Africa: A Trivariate Causality Test, Energy Economics, 31, 635640.

Orta Vadeli Program OVP (2017-2019), http://www.kalkinma.gov.tr/Lists/Yaynlar/Attachments/722/Or ta\%20Vadeli\%20Program\%20(2017-2019).pdf, (Erişim Tarihi; 12/03/2017).

Omri, A., (2013). CO2 Emissions, Energy Consumption And Economic Growth Nexus in MENA Countries: Evidence From Simultaneous Equations Models, Energy Economics, Vol. 40, 657-664.

Özata E. (2010). Türkiye'de Enerji Tüketimi ve Ekonomik Büyüme Arasındaki ilişkilerin Ekonometrik incelemesi, Dumlupınar Dergisi, Nisan, https://birimler.dpu.edu. tr/app/views/panel/ckfinder,.

Park, J. (1992). Canonical Cointegrating Regressions, Econometrica, 60, 119143.

Paul, S. \& Bhattacharya R.N. (2004), Causality Between Energy Consumption and Economic Growth in India: A Note on Conflicting Results, Energy Economics, 26, 977-983.

Payne, J. E. (2009), On the Dynamics of Energy Consumption and Output in the US, Applied Energy, 86,575-577.

Perron, P., (1989). The Great Crash, the Oil Price Shock, and the Unit Root Hypothesis, Econometrica, 57(6), 1361-1401.

Ruhul A.S., Kamrul H. \& Sahar S. (2014), Renewable and Non-Renewable Energy Consumption and Economic Activities: Further Evidence From OECD Countries, Energy Economics, 44, 350-360.

Stern, D. I. (1993), Energy Use and Economic Growth in the USA, A Multivariate Approach, Energy Economics, 15(2), 137-150.

Stern, D. I. (2000), A Multivariate Cointegration Analysis of the Role of Energy in the US Macroeconomy, Energy Economics, 22, 267-283.

Stock, J. H. \& Watson M. (1993). A Simple Estimator Of Cointegrating Vectors in Higher Order Integrated Systems, Econometrica, 61, 783820 .

Şengül, S. ve Tuncer İ. (2006). Türkiye'de Enerji Tüketimi ve Ekonomik Büyüme:1960-2000, Iktisat Isletme ve Finans Dergisi, 21(242), 69-80. 
Soytaş, U. \& Sarı R. (2003), Energy Consumption and GDP: Causality Relationship in G-7 Countries and Emerging Markets, Energy Economics, 25, 33-37.

Tatlı H. (2015). Çok Değişkenli Bir Üretim Modeli ile Toplam Enerji Tüketimi ve Ekonomik Büyüme İlişkisi: Türkiye Örneği, Hacettepe Üniversitesi İktisadi ve İdari Bilimler Fakültesi Dergisi, 33 (4), 135-157.

Tsani, Z.S.(2010) Energy Consumption and Economic Growth: A Causality Analysis for Greece, Energy Economics 32, 582-590.

Uzunöz, M. ve Akçay Y. (2012). Türkiye'de Büyüme ve Enerji Tüketimi Arasındaki Nedensellik İlişkisi, Cankırn Karatekin Üniversitesi SBE Dergisi, 3(2), 1-16.

Wong, S. L., Chang Y. \& Chia W. M. (2013). Energy Consumption, Energy R\&D and Real GDP in OECD Countries With and Without Oil Reserves, Energy Economics, 40, November, 51-60.

Yalta A. T. (2013). Analyzing Energy Consumption and GDP Nexus Using Maximum Entropy Bootstrap:The Case of Turkey, Energy Economics, 33, 453-460.

Yanar R. \& Kerimoğlu G. (2011). Türkiye'de Enerji Tüketimi, Ekonomik Büyüme ve Cari Aç1k İlişkisi, Ekonomi Bilimleri Dergisi, 3(2), 191-201.

Yang, H. Y. (2000). A Note on the Causal Relationship Between Energy and GDP in Taiwan, Energy Economics, 22(3), 309-317.

Yu, E. S. H. \& Hwang D. B. K. (1984), The Relationship Between Energy and GNP, Energy Economics, 6(3), 186-190.

Yu, E. S. H. \& Jin C. (1992), Cointegration Tests of Energy Consumption, Income and Employment, Resources and Energy, 14(3),259-266.

Yuan, J., Zhao C. \& Yu S. \& Hu Z. (2007), Electricity Consumption and Economic Growth in China: Cointegration and Co-Feature Analysis, Energy Economics, 29,1179-1191.

Zivot, E. \& Andrews D. W. K. (1992). Further Evidence on the Great Crash, the Oil Price Shock and the Unit Root Hypothesis, Journal of Business and Economic Statistics, 10(3), 251-270.

Zou, G. ve Chau K. W. (2006). Short and Long-Run Effects Between Oil Consumption and Economic Growth in China, Energy Policy, 34, 3644-3655. 